\title{
PERANAN KREATIVITAS PENDIDIK DALAM MENGAJAR PENDIDIKAN AGAMA ISLAM (PAI) KONTEKS MASA KINI
}

\author{
Mar'atul Lutfiyah \\ Universitas Wahid Hasyim Semarang \\ Email: mlutfiyah@gmail.com
}

\begin{abstract}
In this era of development, the prosperity and glory of society depends on creativity, in the form of new ideas, new discoveries and new technologies. To achieve this, attitude and creative behavior need to be planted early. Educator creativity is an important thing in learning and can be an entry point in an effort to improve student learning outcomes. Learning behaviors reflected by educators tend to be less meaningful if they are not rewarded with creative ideas or ideas and learning behaviors. Traditional and modern Islamic Education Learning is also part of the creativity carried out by educators. Religious educators have an important position and role in the learning process and character formation of students.
\end{abstract}

Keywords:Teacher creativity and Teaching Islamic Education.

\begin{abstract}
Abstrak
Dalam era pembangunan ini, kesejahteraan dan kejayaan masyarakat bergantung pada kreativitas, berupa ide-ide baru, penemuan-penemuan baru dan teknologi baru. Untuk mencapai hal ini, perlu sikap pemikiran dan perilaku kreatif ditanam sejak dini. Kreativitas pendidik merupakan hal penting dalam pembelajaran dan dapat menjadi pintu masuk dalam upaya meningkatkan pencapaian hasil belajar peserta didik. Perilaku pembelajaran yang dicerminkan oleh pendidik cenderung kurang bermakna apabila tidak diimbanngi dengan gagasan atau ide dan perilaku pembelajaran yang kreatif. Pembelajaran Pendidikan Agama Islam yang tradisional maupun modern juga merupakan bagian dari kreativitas yang dilakukan oleh pendidik. Pendidik agama memiliki posisi dan peran penting dalam proses pembelajaran dan pembentukan karakter peserta didik.
\end{abstract}

Kata Kunci: Kreativitas Pendidik dan Pembelajaran Pendidikan Agama Islam 


\section{A. Latar Belakang}

Pendidikan pada hakikatnya merupakan usaha untuk membantu peserta didik dalam mengmbangkan dan menitikberatkan pada kemampuan pengetahuan, kecerdasan, nilai atau pola tingkah laku yang berguna. Pendidikan bertanggung jawab untuk memandu dan memupuk kreativitas peserta didik. Yang memegang kunci dalam pembangkitan dan pengembangan daya kreativitas peserta didik adalah pendidik. Seorang pendidik yang ingin membangkitkan kreativitas pada anak-anak didiknya, terlebih dahulu harus berupaya supaya diri sendiri kreatif. Pada umumnya pendidik yang kreatif itu pernah dididik oleh orangorang yang kreatif dalam lingkungan pendidikannya. Kreativitas harus mengubah konsep lama, yang mengatakan bahwa pendidikan ini suatu sistem, dimana faktor-faktor yang telah terdahulu terkumpulkan, dipelihara dan disistimatisasikan.

Dalam Kurikulum 2013, peserta didik dituntut lebih aktif dalam belajar, dimana hal ini bertujuan untuk membentuk karakter berfikir kritis, kreatif, dan mandiri. Kurikulum 2013 menuntut adanya pola pikir pendidik yang dirubah, bahwa proses pembelajaran bukan hanya dari pendidik. Namun bagaimana agar ada keinginan dalam mencari ilmu berasal dari peserta didik. Peserta didik harus lebih aktif bertanya kepada pendidik, dan peserta didik harus juga bisa mencari refrensi atau contoh soal di internet dan belajar di rumah. Karena itu pendidik harus mampu melaksanakan proses belajar mengajar sesuai dengan tema yang dikaitkan dengan kondisi nyata peserta didik, berpusat pada peserta didik, dan peserta didik dituntut aktif dalam pembelajaran.

Di antara karakteristik dari kurikulum tahun 2013 adalah mengembangkan keseimbangan antara pengembangan sikap spiritual dan sosial, rasa ingin tahu, kreativitas, kerja sama dengan kemampuan 
intelektual dan psikomotorik, dan mengembangkan sikap, pengetahuan dan keterampilan serta menerapkannya dalam berbagai situasi di sekolah dan masyarakat. ${ }^{1}$ Untuk itu, seorang pendidik perlu mengembangkan kreativitas sebagai upaya pembaharuan proses pembelajaran di sekolah, maka seorang pendidik dipersyaratkan memunyai pandangan atau pendapat yang positif terhadap bagaimana menciptakan situasi dan kondisi belajar yang diharapkan, karena secara operasionalnya pendidiklah yang terlibat langsung dalam proses pembelajaran di sekolah. Tugas pendidik sangatlah lengkap, sehingga pendidik dituntut untuk menguasai sejumlah ilmu pengetahuan serta keterampilan yang diperlukan dalam pembelajaran.

Dalam proses belajar mengajar pendidik memunyai tugas untuk mendorong, membimbing dan memberi fasilitas belajar bagi peserta didik untuk mencapai tujuan. Pendidik memunyai tanggung jawab untuk melihat segala sesuatu yang terjadi dalam kelas untuk membantu proses perkembangan anak. Pendidik harus memiliki kemampuan profesional dalam tugasnya dengan menerapkan konsep teknologi pembelajaran untuk memecahkan masalah-masalah pendidikan atau pembelajaran.

Begitu penting keberadaan pendidik dalam pembelajaran sehingga sangat disayangkan jika sampai muncul ungkapan seperti yang dikutip Alomary dalam sebuah diskusi pedagogis dengan Sugata Mitra, yaitu "Do we need teachers?" dan dilanjutkan dengan "Kids Can Teach Themselves". 2 Juga penyataan Michele Schweisfurth yang menyatakan

${ }^{1}$ Permendikbud Nomor 67 tahun 2013 tentang Kerangka Dasar dan Struktur Kurikulum SD/MI. Lihat juga Permendikbud Nomor 68 tahun 2013 tentang Kerangka Dasar dan Struktur Kurikulum SMP/MTs dan Permendikbud Nomor 69 tahun 2013 tentang Kerangka Dasar dan Struktur Kurikulum SMA/MA.

${ }^{2}$ Alomary BA, Nunn C.L, White B.J., Williams S.L \& Clark M.D. (2017), Teachers Are They Really Needed? Creative Education. https://doi.org/10.4236/ce.2017.813147, hlm. 2165. 
bahwa "Teachers are not fundamentally different from learners". Pernyataan Sugata tersebut seolah-olah ingin menghilangkan keberadaan dan peran penting pendidik dalam proses pembelajaran peserta didik. Sementara pernyataan Michele Schweisfurth menjelaskan bahwa pendidik dan peserta didik sebenarnya tidak jauh berbeda, sehingga pendidik seharusnya tidak mengalami kesulitan membawa peserta didik menemukan menarik dan asiknya dunia belajar.

Berdasarkan latar belakang di atas, maka tulisan ini akan membahas mengenai peranan kreativitas pendidik dalam mengajar Pendidikan Agama Islam dalam konteks masa kini.Hal ini karena pendidik melaksanakan tugas pengajaran mata pelajaran Pendidikan Agama Islam dengan cara menerjemahkan sendiri setiap ayat dan hadits tanpa melibatkan langsung peserta didik untuk mempraktikkannya secara individu atau kelompok. Keadaan seperti ini yang umum terjadi di Sekolah karena waktu pembelajaran PAI sangat minim, sehingga peranan dari pendidik dengan membuat kreativitas pembelajaran inilah sangat membantu pemahaman peserta didik.

\section{B. Pengertian Kreativitas Pendidik dalam Pembelajaran}

Kata "kreatif" dalam Kamus Umum Bahasa Indonesia diartikan dengan memiliki daya cipta, memunyai kemampuan untuk mencipta atau bersifat mencipta, dengan dijelaskan bahwa sesuatu pekerjaan yang kretif menghendaki selain kecerdasan juga imajinasi. ${ }^{4}$

Menurut Suharman, "Kreativitas dapat didefinisikan sebagai aktivitas kognitif atau proses berfikir untuk menghasilkan gagasan-

${ }^{3}$ Michele Schweisfruth, Learner Centred Education in Developing Country Contexts: From Solution to Problem? International Jurnal of Educational Development 31 (2011), www.elsevier.com/locate/ijedudev.doi.10.1016/j.ijedudev.2011.03.005, hlm. 430.

${ }^{4}$ WJS Purwadaminta, Kamus Umum Bahasa Indonesia, (Jakarta: Balai Pustaka, 2007), hlm. 619. 
gagasan yang baru dan berguna". 5 Telah dapat kita buktikan bahwa belajar dengan melibatkan peserta didik dalam pembelajaran, maka dapat dengan mudah peserta didik lebih memahami materi yang disampaikan oleh pendidik, salah satunya dengan kreativitas seorang pendidik dalam pembelajaran. Kreativitas seorang pendidik dalam menyampaikan materi pelajaran sangatlah penting, karena dengan pendidik kreatif peserta didik aktif dalam mengikuti pelajaran dapat memperlancar interaksi pendidik dan peserta didik dengan maksud untuk membantu peserta didik belajar secara optimal.

Sementara National Advisory Committee on Creative and Curtural Education (NACCCE) memaknai kreativitas sebagai "Imaginative activity fashioned to as to produce outcomes that are both original and of value" ${ }^{6}$ Menurut mereka bahwa kreativitas merupakan aktivitas kebiasaan yang biasa dilakukan dengan penuh imajinatif untuk menghasilkan capaian yang asli (orisinil) dan bernilai. Pengertian ini mereka ambil dari pemahaman bahwa proses-proses kreatif setidaknya terdapat empat karakteristik di dalamnya yaitu a) melibatkan pemikiran dan sikap yang imajinatif, b) semua aktivitas imajinatif dilakukan dengan maksud tertentu untuk mencapai sebuah tujuan, c) proses menghasilkan sesuatu Yng orisinil, dan d) hasil dari kreativitas merupakan sesuatu yang bernilai jika dihubungkan dengan tujuan yang hendak dicapai.

Sebagaimana dijelaskan,

"Out starting point is to recognise four characteristice of creative processes. First, they always involve thinking or behaving imaginatively. Second, overall this imaginative activity is purposeful. That is, it is directed to achieving an objective. Third,

${ }^{5}$ Suharman, Psikologi Kognitif, (Surabaya: Srikandi, 2005), hlm. 373.

${ }^{6}$ National Advisory Committee on Creative and Cultural Education (NACCCE) Report, All out futures: Creativity, Culture and Education. May, 1999, hlm. 31. 
these processes must generate something original. Fourth, the outcome must be of value in relation to the objective".

Dengan demikian kreativitas adalah kemampuan untuk mencipta dan berkreasi. Tidak ada satupun pernyataan yang dapat diterima secara umum mengenai mengapa suatu kreasi timbul. Kreativitas mengacu pada dua hal penting yakni kemampuan menghasilkan sejumlah gagasan pemecahan masalah dan keluwesan, menemukan beragam gagasan yang berbeda-beda.

Sementara pengajaran atau pembelajaran kreatif menurut Keith Sawyer adalah:

"Creative teaching is disciplined improvisation because it always occurs within broad structures and frameworks. Export teachers use routines and activity structures more than novice teachers, but they are able to involce and apply these routines in a creative, improvizational fashion".

Menurutnya creative teaching merupakan improvisasi yang disiplin karena selalu dilakukan dalam konsep dan kerangka kerja. Sehingga akan terlihat berbeda antara pendidik yang sudah terbiasa mengajar dengan pendidik yang baru mengajar, mereka mampu melibatkan dan menerapkan rutinitas mengajarnya dalam kebiasaan yang kreatif dan penuh improvisasi. Creative teaching penuh dengan improvisasi dan suasana kelas yang partisipatif menghasilkan efektifitas pembelajaran dan terwujudnya kerjasama yang alami.

Pendidik kreatif adalah mereka yang secara teratur menempatkan diri mereka di sekitar ide-ide baru yang muncul dari berbagai sumber. Orang yang tidak kreatif adalah orang yang sering mengalami

\footnotetext{
${ }^{7}$ Ibid

${ }^{8} \mathrm{R}$. Keith Sawyer, Creative Teaching, Collaborative Discussion as Disciplined Improvisation, Educational Researcher, March 2004, https://doi.org/10.15516/cie.v19i0.2433, hlm. 13.
} 
kegagalan, yaitu mereka yang terus menerus mengulang-ulang berbagai ide lama yang sudah usang dengan sedikit sekali imajinasi dan kreativitas.

Kesiapan mental pendidik dalam menerima dan mengembangkan kurikulum di sekolah melalui kreativitas, diharapkan terjadi interaksi pembelajaran antara peserta didik dan pendidik dengan bahan belajar. Selama ini pendidik hanya menurunkan apa yang ada di buku kepada peserta didik tanpa memberikan ruang untuk mencoba kreativitas dari bahan yang ada di buku pedoman. Akhirnya hasil dari produk itu hanyalah sebuah kepintaran tanpa diikuti kecerdasan.

Seorang pendidik yang memiliki kreativitas jauh lebih berhasil dalam mengajar dibanding dengan pendidik yang pintar tetapi tidak kreatif. Terlebih pada pendidik di tingkat sekolah rendah karena rasa ingin tahu mereka sangat tinggi dan merupakan masa pertumbuhan yang sangat menentukan keberhasilannya di masa yang akan datang. Sayang jika rasa keingintahuan mereka terkubur sia-sia hanya karena pendidiknya tidak memiliki kreativitas dalam proses belajar mengajar.

Pendidik yang kreatif berusaha untuk menyediakan sebanyak mungkin ruang bagi peserta didik dalam proses pembelajaran. Proses pembelajaran diselenggarakan secara interaktif, inspiratif, menyenangkan, menantang dan memotivasi peaerta didik untuk kreatif dan berpartisipasi aktif, serta memberikan ruang yang cukup bagi prakarsa. Kreativitas dan kemandirian sesuai dengan bakat, minat, dan perkembangan fisik serta psikologis peserta didik. ${ }^{9}$

Oleh karena itu, kreativitas merupakan hal yang sangat penting dalam pembelajaran dan pendidik dituntut untuk mendemonstrasikan

${ }^{9}$ Peraturan Pemerintah Nomor 19 Tahun 2005 tentang Standar Nasional Pendidikan Bab IV tentang Standar Proses Pasal 19 Ayat 1. 
dan menunjukkan proses kreativitas tersebut. Suasaana belajar aktif perlu diatur strategi dan konsepsinya dengan cara menciptakan kiat-kiat tertentu, melalui peran pendidik yang kreatif.

Menjadi pendidik kreatif ternyata tidak mudah, hanya sebagian kecil saja dari pendidik-pendidik yang ada yang dapat menjadi pendidik aktif. Suatu saat seorang pendidik dapat menjadikan dirinya begitu kreatif di mata para peserta didiknya. Kinerja pendidik merupakan serangkaian hasil dari proses dalam melaksanakan pekerjaannya yang sesuai dengan tugas pokok dan fungsinya.

Pendidik yang kreatif dapat dilihat dari beberapa karakteristik yang dimilikinya yang disebut oleh Gramer sebagai personal characteristic, yaitu Enthusiasm, passion and commitment, Risk taking, A clear set of personal values. Willingness to be intuitive and or instropective, Gregarious and instropective. A deep curiosity or questioning stance. A wareness of self as a creative being. ${ }^{10}$ Antusias memiliki semangat dan komitmen, berani mengambil risiko, berkpribadian yang bersih, memiliki intuisi, suka berteman dan berinstropeksi, penuh keingintahuan, memiliki kesadaran bahwa dirinya adalah orang yang kreatif.

Di samping itu, Grainer juga menjelaskan bahwa terdapat beberapa ciri yang ditemukan dalam proses pembelajaran kreatif yaitu:1) a learner centred ethos, 2) a questioning stance, 3) creating space, time and freedom to make connections, 4) employing multi modal teaching approaches, 5) prompting full engagement, ownership and ongoing

${ }^{10}$ T. Grainger, Dan Barnes, J., Creativity in the Primary Curriculum dalam J. Arthur, T. Grainger and D. Wray, (eds.), Learning to Teach in The Primary School, (London: Routledge, 2006), hlm. 213. 
reflection, 6) modelling risk taking and enabling the children to take risks too. ${ }^{11}$

Pembelajaran yang menggunakan semangat learner memberiakn kesempatan yang luas bagi peserta didik untuk secara aktif menemukan pemahaman dengan cara mereka sendiri. Creative teaching juga dapat memunculkan banyak pertanyaan yang dikemukakan oleh pendidik maupun peserta didik karena semua peserta didik memiliki kesempatan untuk berimajinasi, bertanya maupun memberikan jawaban atas pertanyaan yang diajukan. Kemudian waktu yang cukup yang diberikan memberi kesempatan peserta didik untuk melakukan koneksi atas makna dan pemahaman terhadap kajian atau tema yang sedang dibahas.

Tema yang mengajar dengan creative teaching akan menggunakan potensi dan kemampuannya dalam mengajarkan materi-materi tertentu dengan berbagai pendekatan yang sesuai dengan materi-materi tersebut. Pendidik yang mampu memberi dan menerima kritik atau masukan dan evaluasi dengan cara-cara yang baik. Serta dalam keadaan tertentu, bisa saja pendidik melakukan kesalahan kemudian mengakui kesalahan tersebut dan memerbaikinya, kemudian memberikan masukan kepada peserta didik agar tidak "takut" melakukan kesalahan yang tidak disengaja namun segera menyadari dan memerbaikinya.

Dari kreativitas, pendidik akan mendorong peserta didik untuk berani melakukan beberapa hal:

1. Encourage students to learn independently,

2. Have a cooperative, socially integrative style of teaching,

3. Motivate their students to master factual knowledge so that they have a solid base for divergent thinking,

4. Delay judging students ideas until they have been thoroughly worked out and clearly formulated,

${ }^{11}$ T. Grainger, Dan Barnes, J., Creativity in the Primary Curriculum . . . , hlm. 213 214. 
5. Encourage flexible thinking,

6. Promote self evaluation in students,

7. Take students suggestions and questions seriously,

8. Offer students opportunities to work with a wide variety of materials and under many different conditions,

9. Help students learn to cope with frustation and failure so that they have the courage to try the new and unusual. ${ }^{12}$

Pendidik yang kreatif akan mendorong peserta didiknya untuk berani belajar secara mandiri, memiliki styleatau model pangajaran yang integratif dan kooperatif, memotivasi peserta didik untuk menguasai pengetahuan yang faktual sehingga mereka memiliki dasar pengetahuan yang kuat ketika menghadapi pemikiran yang berbeda-beda, tidak tergesa-gesa memberikan penilaian terhadap pemikiran peserta didik sehingga mereka selesai dalam merumuskan tugasnya, mendorong flaksibitas dalam berfikir,mengenalkan evaluasi diri, menerima uraian dan pertanyaan peserta didik dengan sungguh-sungguh, menawarkan kesempatan kepada peserta didik untuk belajar dengan berbagai materi dan berbagai kondisi, serta membantu peserta didik agar mampu belajar mengatasi frustasi dan kegagalan sehingga mereka memiliki keberanian untuk mencoba melakukan sesuatu yang baru dan tidak biasanya.

Sementara Iskandar Agung menjelaskan bahwa dalam mengembangkan kreativitasnya seorang pendidik perlu memerhatikan prinsip-prinsip pendidikan yakni: ${ }^{13}$

1. Pendidik perlu memberi kepercayaan kepada kelas agar kelas memilih belajar secara terstruktur,

2. Pendidik dan peserta didik membuat kontrak kerja,

${ }^{12}$ Dislike Hondzel, Catharine M., "Fostering Creativity: Ontario Teachers Perceptions, Strategies, and Experiences" (2013), Electronic Thests and Dissertation Reposittory, http://ir.lib.uwo.ca/etd/1173, hlm. 28.

${ }^{13}$ Iskandar Agung, Meningkatkan Kreativitas Pembelajaran Bagi Guru, (Jakarta: Bestari Buana Murni, 2010), hlm. 24. 
3. Pendidik perlu menggunakan metode inkuiri atau belajar mencarikan (discovery learning).

4. Pendidik perlu menggunakan metode simulan,

5. Pendidik perlu mengadakan latihan kepekaan agar peserta didik mampu menghayati perasaan dan berpartisipasi dengan kelompok lain,

6. Pendidik harus bertindak sebagai fasilitator belajar, dan

7. Pendidik perlu menggunakan pengajaran berprogram agar tercipta peluang bagi peserta didik untuk timbulnya kreativitas.

\section{Kreativitas Pendidik dalam Pembelajaran PAI}

Proses pembelajaran adalah suatu hal yang penting dalam sebuah pedidikan karena interaksi pembelajaran adalah kegiatan inti pembelajaran yang dapat menjadi sarana transfer keilmuan dari pendidik dengan peserta didik yang terstruktur dan terencana sehingga akan menjadikan peserta didik paham akan materi pelajaran yang disampaikan oleh pendidik. Keberhasilan pendidikan akan dapat dilihat dari hasil belajar atau prestasi belajar yang dicapai oleh peserta didik yang merupakan bagian dari usaha dan suatu kegiatan belajar yang berupa perubahan tingkah laku yang dialami oleh subjek belajar di dalam suatu interaksi dengan lingkungannya. ${ }^{14}$

Dalam proses belajar mengajar pendidik memunyai tugas untuk menolong, membimbing dan memberi fasilitas belajar bagi peserta didiknya untuk mencapai tujuan. Secara rinci tugas seorang pendidik adalah sebagai berikut:

${ }^{14}$ Muhammad Fathurrohman dan Sulistyorini, Belajar dan Pembelajaran Meningkatkan Mutu Pembelajaran Sesuai Standart Nasional, (Yogyakarta: Teras, 2012), hlm. 119. 
1. Mendidik anak dengan titik berat memberikan arahan dan motivasi pencapaian tujuan baik jangka pendek maupun jangka panjang.

2. Memberi fasilitas pencapaian tujuan melalui pengalaman belajar yang memadai.

3. Membantu perkembangan aspek-aspek pribadi seperti sikap, nilainilai dan penyesuaian diri. ${ }^{15}$

Kreativitas pendidik turut menentukan berhasil tidaknya suatu proses pembelajaran. Langkah kreativitas yang dipilah memainkan peranan utama yang berakhir pada semakin meningkatnya minat belajar peserta didik dengan demikian makin baik kreativitas pendidik makin efektif pada pencapaian tujuan pembelajaran.

Untuk mencapai prestasi belajar peserta didik, dituntut peran pendidik yang kreatif. Pendidik yang kreatif menggunakan segala sesuatu yang dimilikinya untuk mengaktualisasikan pembelajaran aktif guna memotivasi peserta didik, seperti pemikiran, fakta dan ide-ide. Pendidik yang kreatif mampu melakukan proses pembelajaran secara efektif dengan menggabungkan berbagai kontekstual instruksional bahan, strategi pengajaran, pembelajaran media dan pengalaman kehidupan nyata.

Pendidik yang kreatif berusaha untuk menyediakan sebanyak mungkin ruang bagi peserta didik dalam proses pembelajaran. Proses pembelajaran diselenggarakan secara interaktif, inspiraktif, menyenangkan, menantang dan memotivasi peserta didik untuk kreatif dan berpartisiapsi aktif, serta memberikan ruang yang cukup bagi

${ }^{15}$ Slameto, Belajar dan Faktor-faktor yang Mempengaruhinya, (Jakarta: Rineka Cipta, 1995), hlm. 99. 
prakarsa. Kreativitas dan kemandirian sesuai dengan bakat, minat dan perkembangan fisik serta psikologis peserta didik. ${ }^{16}$

Memertimbangkan standar proses pembelajaran seperti yang tertuang dalam Peraturan Pemerintah tersebut maka pendidik sebagai ujung tombak pendidikan dituntut untuk lebih kreatif, mampu menciptakan pembelajaran yang menggairahkan, berkualitas dan menyenangkan. Selain kreativitas, kemampuan pendidik dalam berkomunikasi (terutama dalam proses pembelajaran) dengan peserta didiknya juga menjadi faktor penentu di dalam meningkatkan prestasi belajar peserta didik, karena dengan komunikasi yang dapat dimengerti oleh peserta didik, maka akan mempermudah bagi peserta didik yang bersangkutan untuk memahami pelajaran yang disampaikan oleh pendidiknya.

Kemampuan berkomunikasi pendidik adalah kemampuan pendidik dalam menciptakan iklim komunikatif antara pendidik dengan peserta didik dalam proses pembelajaran. ${ }^{17}$ Kemampuan berkomunikasi pendidik sangatlah penting karena dengan komunikasi yang baik maka pesan-pesan yang disampaikan dapat diterima dengan baik pula, sehingga apa yang menjadi tujuan akan dapat tercapai.

Keberhasilan komunikasi pendidik dalam proses pembelajaran merupakan aset penting bagi pencapaian sasaran atau tujuan pendidikan. Keberhasilan tersebut tercermin pada prestasi belajar yang dicapai peserta didik. Melalui proses komunikasi antara pendidik dan peserta didik dimungkinkannya terjadinya pertukaran informasi sehingga

\footnotetext{
${ }^{16}$ Peraturan Pemerintah Nomor 19 Tahun 2005 tentang Standar Nasional Pendidikan Bab IV tentang Standar Proses Pasal 19 Ayat 1.

${ }^{17}$ Sindang Sari dan Omar Hendro, Pengaruh Kreativitas, Komunikasi, dan Kepemimpinan Guru terhadap Prestasi Belajar Siswa Pada SMP Negeri Di Kecamatan Ilir Timur II Palembang, Jurnal Ecoment Global, Volume 2 Nomor 1 Edisi Februari 2017, hlm. 75
} 
pesertadidik dapat menguasai materi yang dipelajari. Apabila komunikasi yang dilakukan oleh pendidik hanya satu arah, maka sering peserta didik kurang berminat terhadap pelajaran yang akan disampaikan oleh pendidik. Hal ini dapat dilihat dari sikap peserta didik dalam menerima pelajaran. Beberapa diantaranya adalah kebiasaan peserta didik yang berbicara dengan teman sebelahnya pada saat pendidik sedang menyampaikan pelajaran, peserta didik mengantuk, atau peserta didik yang sibuk sendiri dengan mencoret-coret buku.

Pada dasarnya, kreativitas itu Allah SWT telah tunjukkan melalui Firman-Nya dalam QS. Ar-Rum [30] ayat 8

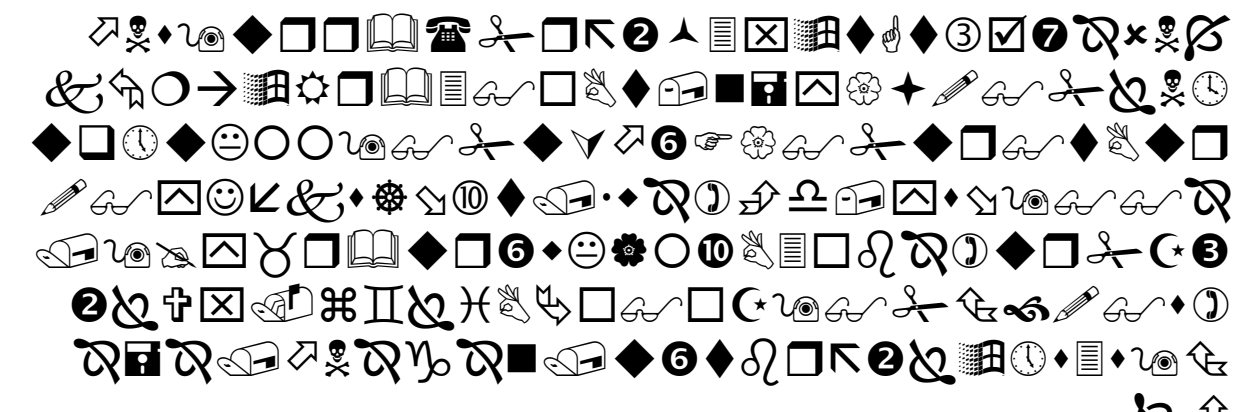

Dan Mengapa mereka tidak memikirkan tentang (kejadian) diri mereka? Allah tidak menjadikan langit dan bumi dan apa yang ada diantara keduanya melainkan dengan (tujuan) yang benar dan waktu yang ditentukan. dan Sesungguhnya kebanyakan di antara manusia benar-benar ingkar akan pertemuan dengan Tuhannya. ${ }^{18}$

Ayat di atas menunjukkan bahwa Allah SWT menganjurkan kepada semua manusia untuk berfikir dan mengembangkan ide karena manusia adalah makhluk yang diberikan Allah SWT akal yang tidak dimiliki oleh makhluk lainnya.

Kreativitas pendidik dalam pembelajaran sangat berpengaruh terhadap pemahaman peserta didik, karena semakin pendidik kreatif

\footnotetext{
${ }^{18}$ Departemen Agama RI. Al-Qur'an dan Terjemahnya (Jakarta: Gema Risalah Press, 1992), hlm. 642.
} 
dalam menyampaikan materi maka semakin mudah peserta didik memahami pelajaran dan menjadikan peserta didik lebih kreatif dalam belajar. Apabila pendidik semakin kreatif dalam pembelajaran maka peserta didik tidak akan mengalami kejenuhan dalam mengikuti pelajaran. Pendidik pun akan lebih mudah menciptakan suasana kelas yang kondusif.

Pembelajaran efektif juga akan melatih dan menanamkan sikap demokrasi bagi peserta didik. Lebih dari itu, pembelajaran yang efektif menekankan bagaimana agar peserta didik mampu belajar cara (learning how to learn). Melalui kreativitas pendidik, pembelajaran di kelas menjadi sebuah aktivitas yang menyenangkan. Proses aktivitas belajarmengajar yang tentunya menyenangkan tidak tercipta begitu saja akan tetapi pengelolaannya dirancang oleh guru dengan merancang fasilitas belajar (media), sehingga aktivitas belajar peserta didik menjadi dipermudah dan mendorong proses belajar peserta didik. Kreativitas bisa dikembangkan dengan penciptaan proses pembelajaran yang memungkinkan peserta didik dapat mengembangkan kreativitasnya. Salah satu bentuk yang perlu ditunjukkan kreativitas pendidik dalam proses pembelajaran yaitu memanfaatkan berbagai sumber belajar dan media pembelajaran agar mempertinggi hasil belajar yang dicapai.

Dalam proses pembelajaran untuk pengembangan kreativitas pendidik berfungsi sebagai fasilitator dan memberikan arahan kepada peserta didik. Penstrukturan kegiatan lebih longgar. Namun, tagihan yang harus dipenuhi telah ditetapkan sebelumnya secara eksplisit. Proses pembelajaran berjalan sesuai dengan sasaran yang ditetapkan. Mekanisme pemantauan bahkan yang relatif serta sistematis sangat diperlukan. Sifat kemandirian yang dialami peserta didik dalam pembelajaran lebih banyak dilakuakn di luar kontrol pendidik. 
Pembiasaan peserta didik belajar secara mandiri merupakan proses membentuk peserta didik menjadi dirinya sendiri dan itu berjalan sepanjang hidup. Untuk mewujudkan kemandirian peserta didik. Setahap demi setahap pendidik harus memberi tanggung jawab kepada peserta didik dan sewaktu-waktu pendidik menaruh diri apabila tandatanda kemandirian itu sudah mulai tumbuh. Pembiasaan anak mandiri merupakan salah satu usaha untuk merealisasikan proses membentuk peserta didik menjadi dirinya sendiri.

Kemandirian peserta didik akan terwujud apabila pendidik sejak awal tidak melindungi secara berlebihan. Perlindungan yang berlebihan cenderung menimbulkan keterganttungan peserta didik yang berlebihan pada semua orang. Di samping itu, hal itu berakibat kurangnya rasa percaya diri. Dengan demikian, anak relatif sulit mencapai kemandirian.

Kreativitas baru akan muncul apabila dalam pembelajaran oleh pendidik didukung dengan pemahaman tentang makna mengajar dan belajar. Mengajar bukan hanya sekedar memberikan materi atau pun melaksanakan hal-hal tertentu, apalgi jika dikaitkan dengan pencapaian target program pngajaran. Belajar juga tidak melulu hanya mengingat apa yang dijejalkan pendidik atau buku pelajaran kepada peserta didik selama kegiatan belajar mengajar. Pendidik bukan sekedar menitikberatkan sebagai penyampai pengetahuan dan pengalih keterampilan serta merupakan satu-satunya sumber belajar, tetapi perlu dirubah menjadi pembimbing, pembina, pengajar dan pelatih yang berarti membelajarkan anak didik. ${ }^{19}$

Adapun dalam pembelajaran Pendidikan Agama Islam (PAI), pendidik dapat menyesuaikan apakah menggunakan model pembelajaran tradisional yang lebih berpusat pada pendidik atau pembelajaran terbaru

${ }^{19}$ Iskandar Agung, Meningkatkan Kreativitas Pembelajaran Bagi Guru . . . , hlm. 23. 
atau modern yang lebih banyak menuntut peserta didik agar lebih aktif. Sebagaimana yang disampaikan oleh Tsu Pu Wang:

In traditional teaching, a teacher plays an important role in the instructional activities. Their teaching style is highly teacher driven. The teacher usually dominates and controls the activities of the whoe class. ${ }^{20}$

Namun penggunaan metode atau pendekatan pembelajaran PAI yang tradisional maupun modern juga merupakan bagian dari kreativitas yang dilakukan oleh pendidik. Pendidik agama memiliki posisi dan peran penting dalam proses pembelajaran dan pembentukan karakter peserta didik. Di sekolah misalnya,pendidik terlibat dalam proses belajar mengajar, menyiapkan dan menyediakan materi pelajaran serta menyampaikannya kepada peserta didik. Sementara di masyarakat, mereka dianggap memiliki status sosial yang berbeda dengan masyarakat pada umumnya atau bahkan lebih tinggi. Konsep Jawa bahwa pendidik berarti orang yang patut dan harus "digugu lan ditiru" memperlihatkan pengakuan sosial atas peran penting pendidik.

Tugas pendidik tidak hanya menjadikan anak pandai, cerdas dan berwawasan, melainkan membekali peserta didik dengan nilai-nilai dan norma yang mempersiapkan mereka menjadi insan yang bertanggung jawab terhadap diri sendiri, orang lain dan masyarakat. ${ }^{21}$ Sehingga penggunaan kreativitas pendidik dalam mengajar memperhatikan nilainilai agama yang tidak sekedar teori atau sisi normatif saja.

Menurut A. Qodri A. Zizy sebagaimana dikutip Mahfud Junaedi, pendidik di dalam kelas tidak bisa dan tidak cukup hanya menyajikan agama pada dataran normatif kemudian ditagih melalui ujian dan

${ }^{20} \mathrm{Tzu}-\mathrm{Pu}$ Wang, The Comparison of the Difficulties between Cooperative Learning and Traditional Teaching Methods in College English Teachers, The Journal of Human Resource and Adult Learning Vol. 3, Num. 2, December 2007, hlm. 24.

${ }^{21}$ Mahfud Junaedi, Paradigma Baru Filsafat Pendidikan Islam, (Depok: Kencana, 2017), cet. I, hlm. 253. 
hafalan. Pendidik agama juga dituntut untuk menciptakan metode baru sekaligus melakukan "creating a moral community in the classroom" (menciptakan suatu masyarakat atau kelompok bermoral di dalam kelas), "moral discipline", "creating a democratic classroom environtment" (menciptakan lingkungan ruang kelas yang demokratis), "teaching values through the curriculum" (mengajarkan nilai melalui kurikulum), "raising the level of moral discussion" (mengangkat tingkatan diskusi moral), sampai pada "teaching children to solve conflict" (mengajar anak untuk menyelesaikan konflik yang otomatis harus diajarkan tentang toleransi terlebih dahulu). ${ }^{22}$

Peserta didik memang menjadi subjek utama dalam pendidikan, namun pendidik juga punya peranan penting dalam keberhasilan mereka. Pendidik bertugas membimbing peserta didik agar bisa mengembangkan potensi-potensi kebaikan dan karakter-karakter positif dalam diri mereka sehingga bermanfaat bagi dirinya sendiri dan mampumemuliakan kehidupan sesama.

\section{Kesimpulan}

Kreativitas memiliki dua komponen: pentingnya kreativitas dalam aktivitas sehari-hari dan keyakinan pentingnya kreativitas di sekolah. Hal ini jelas bahwa tanpa kreativitas manusia tidak dapat menikmati kesenangan dan makna hidup, dan tanpa kreativitas tidak memiliki seni, literatur, ilmu inovasi, pemecahan masalah, serta kemajuan. Mengembangakn kreativitas di kelas merupakan faktor utama dan penting. Kreativitas dapat dilatih dan diajarkan kepada peserta didik. Pendidik yang melatih dan mengajarkan kreativitas kepada peserta didik, haruslah pendidik yang juga adalah seorang kreator. Pendidik

${ }^{22}$ Mahfud Junaedi, Paradigma Baru Filsafat Pendidikan Islam . . , hlm. 262. 
yang mengerti kreativitas dapat memilih konten, rencana pelajaran, mengorganisasikan materi dan tugas-tugas yang tepat dalam cara membantu peserta didik mengembangkan keterampilan dan sikap penting untuk kreativitas.

Untuk melakukan ini dengan baik, pendidik membutuhkan dasar yang kuat dalam penelitian dan teori tentang kreativitas dan berbagai strategi untuk mengajar dan manajemen yang mengaitkan penelitian dan praktik proses kreativitas sejajar dengan belajar peserta didik yang menggunakan konten dalam cara kreatif, belajar konten dengan baik. Peserta didik juga belajar strategi untuk mengidentifikasi masalah, engambil keputusan dan menentukan solusi di dalam sekolah, dan di luar sekolah, kelas yang diorganisasikan untuk mengembangkan kreativitas menjadi tempat belajar dan menakjubkan yaitu "senang ingin tahu". Selanjutnya didiskusikan apa, bagaimana, mengapa kreativitas diajarkan serta kaitan antara kreativitas dengan motivasi, dan organisasi kelas, dan faktor-faktor yang memengaruhi krativitas.

Oleh karena itu, disarankan agar seorang pendidik perlu mengembangkan kreativitas sebagai upaya pembaharuan proses pembelajaran di sekolah maka seorang pendidik dipersyaratkan memunyai pandangan atau pendapat yang positif terhadap bagaimana menciptakan situasi dan kondisi belajar yang diharapkan pendidik juga memiliki kreativitas dalam menggunakan media-media pembelajaran yang ada dan menggunakan metode yang sesuai dengan materi yang disampaikan. 


\section{DAFTAR PUSTAKA}

Agung, Iskandar. 2010.Meningkatkan Kreativitas Pembelajaran Bagi Guru. Jakarta: Bestari Buana Murni.

Departemen Agama RI. 1992. Al-Qur'an dan Terjemahnya (Jakarta: Gema Risalah Press.

Fathurrohman, Muhammad dan Sulistyorini. 2012.Belajar dan Pembelajaran Meningkatkan Mutu Pembelajaran Sesuai Standart Nasional. Yogyakarta: Teras.

Grainger, T. dan Barnes, J. 2006.Creativity in the Primary Curriculum dalam J. Arthur, T. Grainger and D. Wray, (eds.), Learning to Teach in The Primary School. London: Routledge.

Junaedi,Mahfud. 2017.Paradigma Baru Filsafat Pendidikan Islam. Depok: Kencana.

Peraturan Pemerintah Nomor 19 Tahun 2005 tentang Standar Nasional Pendidikan Bab IV tentang Standar Proses Pasal 19 Ayat 1.

Permendikbud Nomor 67 tahun 2013 tentang Kerangka Dasar dan Struktur Kurikulum SD/MI.

Permendikbud Nomor 68 tahun 2013 tentang Kerangka Dasar dan Struktur Kurikulum SMP/MTs.

Permendikbud Nomor 69 tahun 2013 tentang Kerangka Dasar dan Struktur Kurikulum SMA/MA.

Purwadaminta,WJS.2007. Kamus Umum Bahasa Indonesia. Jakarta: Balai Pustaka.

Sindang Sari dan Omar Hendro, Pengaruh Kreativitas, Komunikasi, dan Kepemimpinan Guru terhadap Prestasi Belajar Siswa Pada SMP Negeri Di Kecamatan Ilir Timur II Palembang, Jurnal Ecoment Global, Volume 2 Nomor 1 Edisi Februari 2017.

Slameto. 1995.Belajar dan Faktor-faktor yang Mempengaruhinya. Jakarta: Rineka Cipta.

Suharman. 2005.Psikologi Kognitif. Surabaya: Srikandi. 
Tzu-Pu Wang, The Comparison of the Difficulties between Cooperative Learning and Traditional Teaching Methods in College English Teachers, The Journal of Human Resource and Adult Learning Vol. 3, Num. 2, December 2007.

Alomary BA, Nunn C.L, White B.J., Williams S.L \& Clark M.D. 2017.Teachers Are They Really Needed? Creative Education. https://doi.org/10.4236/ce.2017.813147.

Hondzel,Dislike, Catharine M., "Fostering Creativity: Ontario Teachers Perceptions, Strategies, and Experiences" (2013), Electronic Thests and Dissertation Reposittory.http://ir.lib.uwo.ca/etd/1173.

National Advisory Committee on Creative and Cultural Education (NACCCE) Report. May, 1999.All out futures: Creativity. Culture and Education.

Sawyer,R. Keith. March, 2004.Creative Teaching, Collaborative Discussion as Disciplined Improvisation.Educational Researcher.https://doi.org/10.15516/cie.v19i0.2433.

Schweisfruth, Michele. 2011. Learner Centred Education in Developing Country Contexts: From Solution to Problem? International Jurnal of Educational Development www.elsevier.com/locate/ijedudev.doi.10.1016/j.ijedudev.2011.03.00 5 , 